\title{
The Creation of Value for Shareholders in Tender Offers: An Empirical Investigation on the Italian Stock Market
}

\author{
Fabrizio Rossi \\ University of Cassino and Southern Lazio, Cassino, Italy
}

\begin{abstract}
The economic and monetary unification, the globalization of markets and the increasing use of new Information and Communication Technologies (ICT) have increased the level of competition in all sectors of the economy by opening the way to processes of Mergers and Acquisitions between companies. In the period of 1990-2006, there were 6,097 acquisitions of corporate control involving the listed companies and the unlisted companies, $10 \%$ of which involved the banking sector. From the 1992 regulation up to 2006, the Antitrust Authority has registered 5,995 takeovers, with an increase of $188.1 \%$ in the period of $1994-2006$. The objective of this work is to investigate the creation of value for shareholders both in tender offers (Offerta Pubblica di Acquisto-OPA) which provide the change of corporate control, and in residual transactions. In this regard, 202 operations involving 45 bidders and 181 targets during the period of 1994-2006 have been examined by using the event study methodology. The cumulative abnormal returns in the changes of corporate control, within 20 days of the announcement date, seem to suggest the creation of value for the target companies $\left(C A R_{t}+7.39 \%\right)$ and a destruction of value for the bidders $\left(C A R_{b}-3.85 \%\right)$. An analysis of the combined values, however, reveals that these overall operations do not create value (CCARs - 0.56\%). In conclusion, these transactions, rather than creating value, produce the transfer of value by the shareholders of the bidder companies to those of the target companies, which ultimately results in a "zero sum”.
\end{abstract}

Keywords: investment decisions, mergers and acquisitions, tender offers, event studies, Italian stock market, cumulative abnormal returns, bidders, targets

\section{Introduction}

The economic and monetary unification, the globalization of markets and the increasing use of new information and communication technologies have increased the level of competition in all sectors of the economy by opening the way to processes of Mergers \& Acquisitions between companies.

In Italy, the acquisition processes have been increased during the first half of the 1990s together with the regulation. The Antitrust Law 287 of 1990 was the first to regulate the Mergers and Acquisitions with the establishment of the Antitrust-Autorità Garante della Concorrenza e del Mercato (AGCM) — whose task is to oversee the competition and the abuse of dominant positions by companies.

Subsequently, with Law 149 of 1992, Public Tender Offers-OPA and the transfer of corporate control

Fabrizio Rossi, Ph.D., Adjunct Professor of Economics and Business Organisation, Department of Electrical and Information Engineering, University of Cassino and Southern Lazio.

Correspondence concerning this article should be addressed to Fabrizio Rossi, University of Cassino and Southern Lazio, Via G. Di Biasio 43, Cassino (FR) 03043, Italy. E-mail: f.rossi@unicas.it. 
are regulated by giving wide powers to the Commissione Nazionale per le Società e la Borsa (CONSOB), a control on the listed companies set up by Law 216 of 1974.

With the introduction of the Testo Unico della Finanza (TUF), established by Legislative Decree 58 of 1998 or Riforma Draghi, Law 149/1992 on Tender Offers has been repealed and regulated in the new text. The last piece of legislation, prior to the analysis, dates back to 2004 with the issuing of EU Directive N. 2004/25/ EC.

The phenomenon of acquisitions is new to our country, and from this point of view, there is a delay compared with Anglo-Saxon countries. The trend of Mergers \& Acquisitions takes on distinctive features when compared with what took place on the international scene both regarding value and number and regarding industry.

In the period of 1990-2006, there were 6,097 acquisitions of corporate control involving the listed companies and the unlisted companies, 10\% of which involved the banking sector. From the 1992 regulation up to 2006, the Antitrust Authority has registered 5,995 takeovers, with an increase of $188.1 \%$ in the period of 1994-2006 (AGCM Annual report, various years).

The aim of this work is to investigate the creation of value for shareholders in total Tender Offers, in Tender Offers with change of control and residual Tender Offers. An overall 202 operations were examined, 82 of which involve the change of corporate control, involving 181 targets and 45 bidders during the period of 1994-2006. The Cumulative Abnormal Returns (CARs) were estimated by using the "event study", considering an estimated interval of 234 days $(-244,-11)$. The results obtained during the testing window $(-10,+10)$ examining the overall sample suggest the creation of value for the targets (CARs $+11.32 \%$ ) and a destruction of value for the bidders (CARs - 1.05\%). The analysis of the OPA with a change of control also shows similar results. The target companies register a creation of value (CARs $+7.39 \%$ ) and the bidders register a destruction of value (CARs - 3.85\%). An analysis of the combined values, however, shows that these overall operations do not create value (CCARs - 0.56\%). In other words, they result in a "zero sum".

\section{Tender Offers (Offerta Pubblica di Acquisto-OPA): Definition and Types}

A Tender Offer (Offerta Pubblica di Acquisto-OPA) is the transfer of securities, the process by which changes are made in corporate control. The subject has been regulated by Law 149/92, now replaced by Legislative Decree 58/98 or Riforma Draghi. In particular, the Tender Offer concerns the irrevocable offer to buy the majority or minority of equity stakes, or convertible bonds, by payment in cash or in securities (OPSC-Public Tender Offer to Exchange).

The Testo Unico della Finanza (TUF) regulates the types of mandatory Tender Offers for the shares of companies listed on regulated markets run by Borsa Italiana SpA-London Stock Exchange Group.

\section{Full and Subsequent Tender Offer (Law 149/92 as Amended by TUF)}

It is promoted by anyone who, as a result of acquisition for consideration, comes to hold a stake of over $30 \%$. The Tender Offer is promoted within 30 days at a price not less than the arithmetic mean between the weighted average market price over the last 12 months and the highest price the bidder agreed to pay over the same period to acquire ordinary shares. It is the Consob's responsibility to discipline, with its own rules, the cases in which the investment is acquired through the purchase of shares in companies whose assets mainly consist of securities issued by other listed companies. The obligation to make an offer is subsequent to purchases by those who already hold a stake of $30 \%$, without having the majority of the voting rights of the 
shareholders. In the previous regulation (Law 149/92) the subsequent OPA was promoted by anyone who had acquired control or a simple majority of the voting rights.

\section{Preventative Tender Offer (Law 149/92 as Amended by TUF)}

An offer subject to having at least $60 \%$ of the ordinary shares of a company listed on an Italian regulated market. In the previous law 149/92, it was intended as a public offer promoted in order to gain control of the company.

\section{Residual Tender Offer (Law 149/92 Included by TUF)}

The bidder who, following a full tender offer, is a shareholder of at least $95 \%$ of the capital represented by securities in an Italian listed company has the obligation to purchase the remaining securities from anyone who requests it. However, if the buyer has a market share of more than $90 \%$ but less than $95 \%$, he/she has the obligation to buy the remaining shares admitted to trading on a regulated market from anyone who requests it if within 90 days he does not reinstate enough floating funds to ensure regular trading.

\section{Incremental Tender Offer (Law 149/92 as Repealed by TUF)}

It is a mandatory Tender Offer promoted by those who hold a share of the voting rights equal to half of the controlling or the majority of stake of a listed company, and it has increased the share by $2 \%$ of the corporate capital within a 12-month period.

Instead, the voluntary Tender Offer is promoted without any legal requirements, and may concern all of the securities or even a smaller share. The preventative OPA, for example, is always voluntary.

The ultimate goal of the legislation, at least in the legislator's intention, was to contribute to the creation of a market for corporate control. A further step in this direction was taken with the Directive 2004/25 EC on April 21, 2004.

Table 1 shows both the number and the value of offers pointed out by CONSOB.

Table 1

Number of OPA and/or OPSC on Stocks of Italian listed Companies and Equivalent in Millions of Euros

\begin{tabular}{llllllllllllllll}
\hline & 1992 & 1993 & 1994 & 1995 & 1996 & 1997 & 1998 & 1999 & 2000 & 2001 & 2002 & 2003 & 2004 & 2005 & 2006 \\
\hline $\begin{array}{l}\text { Number of } \\
\text { transactions }\end{array}$ & & & & & & & & & & & & & & & \\
Voluntary & 5 & 2 & 2 & 4 & 6 & 5 & 2 & 4 & 7 & 4 & 10 & 8 & 4 & 4 & 2 \\
Preventative $^{*}$ & - & 2 & 1 & - & 2 & 2 & 2 & 8 & 8 & 2 & 4 & 4 & - & 1 & - \\
Incremental $^{* *}$ & - & - & - & - & 1 & 1 & 1 & - & - & - & - & - & - & - & - \\
Subsequent & 2 & 3 & 11 & 8 & 9 & 7 & 6 & 8 & 6 & 7 & 4 & 6 & 10 & 12 & 10 \\
Residual & & 5 & 6 & 9 & 10 & 8 & 3 & 2 & 7 & 11 & 5 & 8 & 3 & 4 & 5 \\
Total & $\mathbf{7}$ & $\mathbf{1 2}$ & $\mathbf{2 0}$ & $\mathbf{2 1}$ & $\mathbf{2 8}$ & $\mathbf{2 3}$ & $\mathbf{1 4}$ & $\mathbf{2 2}$ & $\mathbf{2 8}$ & $\mathbf{2 4}$ & $\mathbf{2 3}$ & $\mathbf{2 6}$ & $\mathbf{1 7}$ & $\mathbf{2 1}$ & $\mathbf{1 7}$ \\
Equivalent (€) & & & & & & & & & & & & & & & \\
Voluntary & 611 & 850 & 72 & 75 & 264 & 378 & 96 & 631 & 4,299 & 171 & 3,724 & 5,837 & 142 & 16,593 & 878 \\
Preventative & - & 543 & 1,947 & - & 213 & 234 & 1,658 & 53,292 & 4,878 & 726 & 809 & 7,359 & - & 11 & - \\
Incremental & - & - & - & - & 53 & 4 & 126 & - & - & - & - & - & - & - & - \\
Subsequent & 11 & 12 & 832 & 975 & 161 & 376 & 102 & 640 & 2,734 & 5,573 & 26 & 174 & 293 & 3,007 & 6,046 \\
Residual & - & 7 & 23 & 24 & 14 & 27 & 23 & 5 & 218 & 196 & 44 & 356 & 79 & 82 & 480 \\
Total & $\mathbf{6 2 2}$ & $\mathbf{1 , 4 1 2}$ & $\mathbf{2 , 8 7 4}$ & $\mathbf{1 , 0 7 4}$ & $\mathbf{7 0 5}$ & $\mathbf{1 , 0 1 9}$ & $\mathbf{2 , 0 0 5}$ & $\mathbf{5 4 , 5 6 8}$ & $\mathbf{1 2 , 1 2 9}$ & $\mathbf{6 , 6 6 6}$ & $\mathbf{4 , 6 0 3}$ & $\mathbf{1 3 , 7 2 6}$ & $\mathbf{5 1 4}$ & $\mathbf{1 9 , 6 9 3}$ & $\mathbf{7 , 4 0 4}$ \\
\hline
\end{tabular}

Notes. $^{*}$ : The number of transactions includes concurrent offers; ${ }^{* *}$ : Typology pursuant to law 149/1992 e not to the TUF. Source: Elaboration of data from CONSOB archives. 
For the period of 1992-2006, the number of total Tender Offers is 303 for a total of over 120 billion Euros. The maximum was recorded in 1999, the year when the Olivetti-Telecom OPA, called the "mother of all OPA" was launched. In the period under examination (1994-2006), 284 transactions have been registered for a total of approximately 127 billion Euros. The increase in turnover is recorded after the coming into effect of the TUF.

\section{The Results of Literature on Tender Offers}

Most of the studies discuss the M\&As together, without distinguishing Mergers from Tender Offers. Among the works which focus on Tender Offers, some of which are illustrated in Table 2, the results are not always converging. Many studies, in fact, seem to suggest the creation of value for the shareholders of the companies involved (Dodd \& Ruback, 1977; Kummer \& Hoffmeister, 1978; Bradley, 1980; Jarrell \& Bradley, 1980; Bradley, Desai, \& Kim, 1988; Jarrell \& Poulsen, 1989; Lang, Stulz, \& Walkling, 1989, Smith \& Kim, 1994; Bigelli \& Mengoli, 1999).

Table 2

Studies on Mergers and Tender Offers for Which it Was Possible to Collect Data

\begin{tabular}{|c|c|c|c|c|c|c|c|c|c|}
\hline Study & Period & Country & Event & Sector & $\begin{array}{l}\text { Event } \\
\text { window } \\
\text { (days) }\end{array}$ & Model & $\begin{array}{l}\text { Sample } \\
\text { size }\end{array}$ & $\mathrm{CAR}_{\mathrm{b}}$ & $\mathrm{CAR}_{\mathrm{t}}$ \\
\hline Dodd \& Ruback (1977) & 1958-1978 & USA & $\begin{array}{l}\text { Tender } \\
\text { offers }\end{array}$ & Various & $(0,0)$ & M.M. & 341 & $+2.83 \%^{* *}$ & $+20.58^{* * *}$ \\
\hline $\begin{array}{l}\text { Kummer \& Hoffmeister } \\
\text { (1978) }\end{array}$ & 1956-1974 & USA & $\begin{array}{l}\text { Tender } \\
\text { offers }\end{array}$ & various & $(0,0)$ & M.M. & 105 & $+5.20 \%{ }^{* *}$ & $+16.85 \%^{* * *}$ \\
\hline Bradley (1980) & 1962-1977 & USA & $\begin{array}{l}\text { Tender } \\
\text { offers }\end{array}$ & various & $(-20,+20)$ & CAPM & 392 & $+4.36 \%{ }^{* *}$ & $+32.18 \%^{* * *}$ \\
\hline Jarrell \& Bradley (1980) & 1962-1977 & USA & $\begin{array}{l}\text { Tender } \\
\text { offers }\end{array}$ & various & $(-40,+20)$ & M.M. & 235 & $+6.66 \%{ }^{* * *}$ & $+34.06 \%^{* * *}$ \\
\hline $\begin{array}{l}\text { Bradley, Desai, \& } \\
\text { Kim (1988) }\end{array}$ & 1963-1984 & USA & $\begin{array}{l}\text { Tender } \\
\text { offers }\end{array}$ & various & $(-5,+5)$ & M.M. & 236 & $+0.97 \%^{* * *}$ & $+31.77 \%^{* * *}$ \\
\hline Jarrell \& Poulsen (1989) & 1963-1986 & USA & $\begin{array}{l}\text { Tender } \\
\text { offers }\end{array}$ & various & $(-20,+10)$ & M.M. & 526 & $+0.92 \%{ }^{* *}$ & $+28.99 \%{ }^{* *}$ \\
\hline $\begin{array}{l}\text { Lang, Stulz, \& } \\
\text { Walkling (1989) }\end{array}$ & 1968-1986 & USA & $\begin{array}{l}\text { Tender } \\
\text { offers }\end{array}$ & various & $(-5,+5)$ & M.M. & 174 & $0 \%$ & $+40.30 \%{ }^{* *}$ \\
\hline $\begin{array}{l}\text { Frank, Harris, \& } \\
\text { Titman (1991) }\end{array}$ & 1975-1984 & USA & $\begin{array}{l}\text { Merger } \\
\text { and Tender } \\
\text { offers }\end{array}$ & various & $(-5,+5)$ & 8-factor model & 399 & $-1.45 \%$ & $+28.04 \%{ }^{* *}$ \\
\hline $\begin{array}{l}\text { Kaplan \& } \\
\text { Weisbach (1992) }\end{array}$ & 1971-1982 & USA & $\begin{array}{l}\text { Merger } \\
\text { and Tender } \\
\text { offers }\end{array}$ & various $^{\mathrm{b}}$ & $(-5,+5)$ & M.M & 271 & $-1.49 \%{ }^{* *}$ & $+26.90 \%{ }^{* *}$ \\
\hline Bigelli \& Mengoli (1999) & 1989-1996 & IT & $\begin{array}{l}\text { Tender } \\
\text { offers }\end{array}$ & various & $(-30,+30)$ & M.M. & 56 & $+0.48 \%$ & n.a. \\
\hline Resti \& Siciliano (1999) & 1992-1997 & IT & $\begin{array}{l}\text { Tender } \\
\text { offers }\end{array}$ & Banking & $(-120,+250)$ & M.M. & 14 & $+20.2 \%$ & $+18.7 \%$ \\
\hline $\begin{array}{l}\text { Mulherin \& } \\
\text { Boone (2000) }\end{array}$ & 1990-1999 & USA & $\begin{array}{l}\text { Tender } \\
\text { offers }\end{array}$ & various & $(-1,+1)$ & M.M. & 562 & $-0.37 \%$ & $+21.20 \%{ }^{* * *}$ \\
\hline Rossi (2005) & 1998-2003 & IT & $\begin{array}{l}\text { Mergers } \\
\text { and Tender } \\
\text { offers }\end{array}$ & various & $(-20,+20)$ & M.M. & 66 & $+0.29 \%$ & n.a. \\
\hline $\begin{array}{l}\text { Mulherin \& } \\
\text { Boone (2006) }\end{array}$ & 1989-1999 & USA & $\begin{array}{l}\text { Tender } \\
\text { offers }\end{array}$ & various & $\begin{array}{l}(-1,+1) \\
(-20,+20)\end{array}$ & M.M. & 400 & n.a. & $\begin{array}{l}+21.60 \%^{* * *} \\
+25.40 \%\end{array}$ \\
\hline $\begin{array}{l}\text { Kuipers, Miller, \& } \\
\text { Patel (2008) }\end{array}$ & 1982-1991 & OECD & $\begin{array}{l}\text { Tender } \\
\text { offers }\end{array}$ & various & $(-5,+5)$ & M.M. & 319 & $-1.32 \%^{* * *}$ & $+29.43 \%^{* * *}$ \\
\hline Intrisano \& Rossi (2012) & 1994-2005 & IT & $\begin{array}{l}\text { Mergers } \\
\text { and Tender } \\
\text { offers }\end{array}$ & Banking & $(-30,+30)$ & M.M. & 72 & $-4.27 \%^{*}$ & $+12.32 \%^{* * *}$ \\
\hline
\end{tabular}

Notes. The table illustrates the results of 16 studies on Tender offers. M.M. = Market Model. CAPM = Capital Asset Pricing

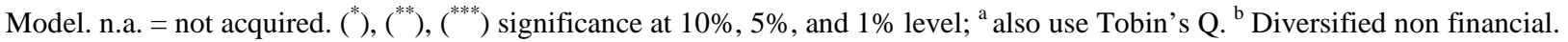

c The study uses the methodology of Fama, Fisher, Jensen, and Roll (1969) and the results refer only to Tender offers.

After analyzing the results of various studies on the abnormal returns created by acquisitions, Jensen and 
Ruback (1983) found that both the targets and the bidders register positive excess returns to the extent of 30\% and 4\%. In other works, however, negative returns are shown for bidder companies (Servaes, 1991; Byrd \& Hickman, 1992; Banerjee \& Owners, 1992; Kaplan \& Weisbach, 1992; Sirower, 1997; Mulherin \& Boone, 2000; Rossi, 2005; Kuipers, Miller, \& Patel, 2008; Intrisano \& Rossi, 2012) ${ }^{1}$.

Jarrell, Brickley, and Netter (1988) carried out an analysis in the 1960-1985 intervals on a sample of 440 bidders and found positive (+1.14\%) and statistically significant values within 15 days of the announcement date. By examining three sub-periods they noted, however, there was a decrease from $+4.40 \%$ to $-1.10 \%$.

In the period of 1979-1985, Jennings and Mazzeo (1991) examined 352 bidders and found negative $(-0.80 \%)$ and statistically significant values between the day before and the date of announcement.

Franks, Harris, and Titman (1991), after examining a sample of Mergers and Tender Offers consisting of approximately 800 companies, found positive and statistically significant returns for the targets and negative but not significant values for the bidders.

Berkovitch and Narayanan (1993) on a sample of 660 companies involved in the processes of Tender Offers in the period of 1963-1988 also found positive and statistically significant values for the targets and negative but not significant values for the bidders.

With regard to the study of acquisitions on the Italian Stock Market, however, the literature is fairly new and this is probably due to the small size of our stock market, and ultimately, due to the lack of a market for corporate control.

The few studies that use the event study in analyzing the processes of Mergers \& Acquisitions in Italy (Caprio, Floreani, \& Radaelli, 1994; Bigelli \& Mengoli, 1999; Resti \& Siciliano, 1999; Savona, 2002; Rossi, 2005; Intrisano \& Rossi, 2012) generally show results that are in line with those produced by international literature.

\section{Sample and Survey Methodology}

The sample was chosen after an extensive survey of all the acquisitions made in the period of 1994-2006 ${ }^{2}$. Another two sub-samples were extrapolated from the overall sample of OPA:

(1) Voluntary and mandatory Tender Offers involve a change of corporate control considering both Laws (149/92 and 58/98): 82 transactions;

(2) Residual tender offers: 51 transactions.

Out of 284 transactions registered by CONSOB (see Table 1), 202 cases of OPA were examined, for which data were available (date of event and time series of stock prices for the entire period). Out of 202 OPA, there was a change in corporate control in 82 cases.

For the definition of the sample, certain criteria were followed, particularly:

(1) that at least one of the two companies was listed continuously throughout both the period of estimate and the period of verification, and that the time series of stock prices in the period of 1994-2006 was available;

(2) that the date of the event $(t, 0)$ was known;

(3) that the companies involved had listed shares with voting rights.

The data were retrieved by using BitStat (the statistics published periodically by the Italian Stock

\footnotetext{
${ }^{1}$ For more details refer to Bruner (2003).

2 The study proposed here differs in two important respects. On the one hand, it considers the effects produced by the two laws (Law 149/92 and TUF); and on the other hand, it examines all the types of OPA regulated in Italy for the 1994-2006 period. Unlike other studies, it not only focuses on the change of company control but also investigates the creation of value for shareholders arising from the overall tender offers.
} 
Exchange), Consob documents and the book "Indici e dati relativi ad investimenti in titoli quotati" (Mediobanca), while the date of the announcement was obtained from the Archives of "Il Sole 24 Ore", a national financial newspaper. The historical prices of stocks were obtained through Datastream. The lack of a specific data bank regarding announcements makes it difficult to identify the exact date, since long before the transaction, there is a leak of news or indiscretion about the occurrence of the event. In this regard, the first date of public announcement of a Tender Offer was used, without waiting for the transaction to be completed (Dodd, $1980)^{3}$.

The abnormal returns were estimated with the Market Adjusted Return Model, using the MIBTEL as a benchmark ${ }^{4}$.

The abnormal returns were estimated as follows:

$$
A R_{i t}=R_{i t}-R_{m t}
$$

where $R_{i t}$ and $R_{m t}$ are respectively the return of the $i$-th security and of the "portfolio" at time $t$ during the monitoring period, considering 234 days as the estimate range (-244, -11).

The Cumulative Abnormal Returns Standardized (CARs) was calculated as follows:

$$
C A R s_{i t}=C A R_{i t-1}+A R_{i t}
$$

Assuming a "buy and hold" strategy for the entire event period.

In order to investigate the market reaction to the announcement of the acquisition, two different time windows around the date of the event have been identified $t \in[-10,+10] \mathrm{e} t \in[-5,+5]$ as well as other asymmetric periods with respect to this date. In particular: $t \in[-10,0], t \in[-5,0], t \in[-1,0]$, for the previous period and $t \in[0,+10], t \in[0,+5], t \in[0,+1]$, for the following period.

Finally, to quantify the value created or destroyed by the transactions as a whole, the combined values of the ARs, and similarly of the CARs, were calculated by using the following formula:

$$
A R_{i}(t)=\frac{M V_{B, i}}{M V_{B, i}+M V_{T, i}} \times A R_{B, i}(t)+\frac{M V_{T, i}}{M V_{B, i}+M V_{T, i}} \times A R_{T, i}(t)
$$

where $A R_{i}(\mathrm{t}), A R_{B, i}(\mathrm{t})$, and $A R_{T, i}(\mathrm{t})$ represent the abnormal returns at time $t$ for the transaction $i, M V_{B}$, and $M V_{T, I}$ the capitalizations of the bidder and target companies, respectively of the last day of estimate ( $\left.t-11\right)$.

For the statistical significance of the results, the methodology suggested by Brown and Warner (1985) ${ }^{5}$ and the sign test ${ }^{6}$ was adopted.

\footnotetext{
${ }^{3}$ A similar approach is followed in other studies as well (Agrawal \& Jaffe, 1996).

4 The MIBTEL index is a general basket which includes all the shares listed on the Stock Exchange and has been active since January 3, 1994. It is a value weighted index that is calculated every minute during the continuous trading phase on the basis of prices. It is preferred to use this index, representative of all securities listed on the Italian stock market, because it is larger and closer to the "market portfolio". It is important to note, finally, that in calculating the returns, all the adjustments (dividends, stock splits, etc.) have been taken into account. Hence, the prices for both the securities and the basket are "Official Price" and "Price Index”, respectively, and were taken, as mentioned above, from Datastream. Currently, it is no longer active as it has been replaced by the FTSE Italy All-Share.

5 Some authors suggest calculating the $t$-test as the ratio between the average ARs and the standard deviation relating to the estimation period which is prior to the verification period in order to avoid increases in variance which could occur around the time of the announcement (Brown \& Warner, 1980, 1985). Others propose a standardization of both ARs and CARs with a procedure that considers the standard deviation of the estimation period and any other increases in variance outside of this period (Patell, 1976).

${ }^{6}$ This is a non-parametric test that becomes indispensable when the hypothesis of normality, independence and identical distribution of the statistical population from which the sample was extracted has not been verified or in the case in which the sample size is particularly small.
} 


\section{Results and Discussion}

In the period of 1994-2006, a total of 202 OPA were examined, of which 82 included the change of company control and concerned 71 target companies and 15 bidders.

\section{The Analysis of Total Tender Offers}

From an analysis of the results, it seems that the target companies register positive and statistically significant values, both at the announcement date $\left(\mathrm{t}_{0}\right) \mathrm{ARs}+4.45 \%$ and in the entire window including the 20 days around the event date CARs $+11.32 \%$.

Contrary to the target, the bidders show negative and significant values at the announcement date ARs $-1.06 \%$, while during the entire period, the CARs of the bidders companies stabilize at $-1.05 \%$ (see Table 3 ).

Table 3

Abnormal Returns Standardized (ARs) of Bidders and Targets ( $t_{0}$ e $\left.t_{+10}\right)$

\begin{tabular}{lllll}
\hline Abnormal Returns Standardized (ARs) & Days & Values & Significance Z-test & Significance sign test \\
\hline \multirow{2}{*}{$\mathrm{ARs}_{\mathrm{B}}$} & 0 & $-1.06 \%$ & $* *$ & - \\
& +10 & $+0.32 \%$ & - & $*$ \\
\hline \multirow{2}{*}{$\mathrm{ARs}_{\mathrm{T}}$} & 0 & $+4.45 \%$ & ${ }^{* * *}$ & - \\
& +10 & $+0.42 \%$ & ${ }^{* * *}$ & - \\
\hline
\end{tabular}

Notes. S.D. = Standard Deviation. $\left({ }^{*}\right),\left({ }^{* *}\right),\left({ }^{* * *}\right)$ Sign test significance at the $10 \%, 5 \%$, and $1 \%$ level.

At the time of the announcement, ARs are statistically significant for both bidders (only Z-test) and targets (Z-test and sign test). Table 4 also includes the sub-periods. As it can be seen, the abnormal variations recorded in each of them are statistically significant: this occurs in the periods prior to the event, in the period including the event and in subsequent periods. The anomalous trends relating to the bidders are, in this case, very small. The greatest cumulative change is recorded in the period $(-5 ; 0)$ with a loss of $-1.68 \%$, although it is not statistically significant. An analysis of abnormal results does not point out considerable variations. However, in sub-periods $(-1 ; 0$ and $0,+1)$ the destruction of value is statistically significant for the $Z$-test ( $p$-value 0.000$)$. The loss of value is equally significant during the entire period around the announcement date $(-10 ;+10)$ and in the sub-period 0 ; +10 with CARs values ranging between $-0.58 \%$ and $-1.05 \%$.

Table 4

Standardized Cumulative Abnormal Returns (CARs) in Total OPA (1994-2006)

\begin{tabular}{|c|c|c|c|c|c|c|c|c|}
\hline \multicolumn{9}{|c|}{ Standardized Cumulative Abnormal Returns (CARs) } \\
\hline \multicolumn{9}{|c|}{ Panel A. Bidders } \\
\hline Period & CARs (\%) & S.D. (\%) & $Z$-test & $p$-value & Pos. & Neg. & Sign test & Significance \\
\hline$(-10 ;+10)$ & -1.05 & 10.11 & -2.9670 & 0.0015 & 15 & 19 & -0.6860 & - \\
\hline$(-5 ;+5)$ & -1.02 & 10.07 & -0.0020 & 0.4992 & 17 & 17 & 0.0000 & - \\
\hline$(-10 ; 0)$ & -1.53 & 9.04 & -0.5035 & 0.3073 & 15 & 19 & -0.6860 & - \\
\hline$(-5 ; 0)$ & -1.68 & 7.36 & 0.0618 & 0.4754 & 18 & 16 & 0.3430 & - \\
\hline$(-1 ; 0)$ & -0.88 & 6.36 & 16.3746 & 0.0000 & 20 & 14 & 1.0290 & - \\
\hline$(0 ; 1)$ & -0.88 & 6.58 & -5.5349 & 0.0000 & 17 & 17 & 0.0000 & - \\
\hline$(0 ; 5)$ & -0.41 & 7.93 & 0.5796 & 0.2811 & 16 & 18 & -0.3430 & - \\
\hline$(0 ;+10)$ & -0.58 & 7.60 & -3.7907 & 0.0001 & 15 & 19 & -0.6860 & - \\
\hline
\end{tabular}


(Table 4 continued)

\begin{tabular}{|c|c|c|c|c|c|c|c|c|}
\hline \multicolumn{9}{|c|}{ Standardized Cumulative Abnormal Returns (CARs) } \\
\hline \multicolumn{9}{|c|}{ Panel B. Targets } \\
\hline Period & CARs (\%) & S.D. (\%) & $Z$-test & $p$-value & Pos. & Neg. & Sign test & Significance \\
\hline$(-10 ;+10)$ & 11.32 & 17.17 & 29.2649 & 0.0000 & 117 & 43 & 5.8502 & *** \\
\hline$(-5 ;+5)$ & 9.26 & 15.14 & 17.6818 & 0.0000 & 112 & 48 & 5.0596 & $* * *$ \\
\hline$(-10 ; 0)$ & 8.53 & 13.24 & 22.1774 & 0.0000 & 116 & 44 & 5.6921 & $* * *$ \\
\hline$(-5 ; 0)$ & 6.87 & 12.63 & 14.9550 & 0.0000 & 113 & 47 & 5.2178 & $* * *$ \\
\hline$(-1 ; 0)$ & 5.86 & 11.06 & 19.1262 & 0.0000 & 114 & 46 & 5.3759 & $* * *$ \\
\hline$(0 ;+1)$ & 5.95 & 11.14 & 10.7985 & 0.0000 & 99 & 61 & 3.0042 & $* * *$ \\
\hline$(0 ;+5)$ & 6.83 & 12.54 & 8.4796 & 0.0000 & 100 & 60 & 3.1623 & $* * *$ \\
\hline$(0 ;+10)$ & 7.24 & 14.46 & 12.1294 & 0.0000 & 99 & 61 & 3.0042 & $* * *$ \\
\hline
\end{tabular}

Notes. S.D. = Standard Deviation. $\left({ }^{*}\right),\left({ }^{* *}\right),\left({ }^{* * *}\right)$ Sign test significance at the $10 \%, 5 \%$, and $1 \%$ level.

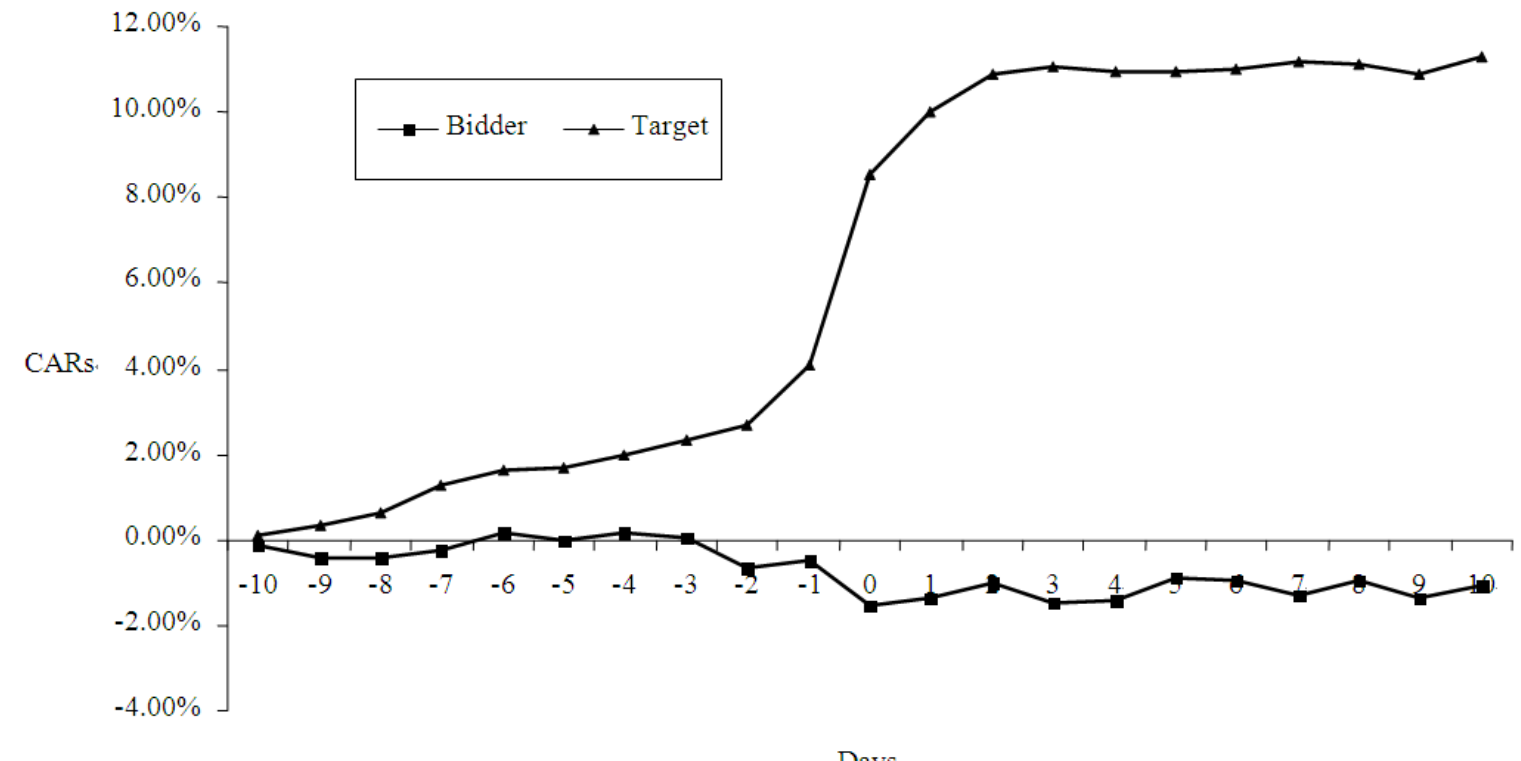

Figure 1. OPA (1994-2006). Number transactions: 202. Sample size: 34 bidder and 160 target.

The trend of the CARs (see Figure 1) varies, according to whether targets or bidders are involved and it would seem that the shareholders of the target company anticipate the news before the announcement date.

\section{The Analysis of Tender Offers With a Change of control}

A less pronounced but similar trend is also found in the case in which the OPA expects a change of corporate control (see Figure 2). The result is fairly surprising as one would expect an increase with regard to CARs obtained in the analysis of the targets of Tender Offers without change of control (+11.32\%). The difference should come from the majority of premium paid by the buyer. The CARs of the bidders show a flat trend up to the release of the news. Unlike the bidder, the target companies seem to anticipate the news immediately, and after the announcement date they show a linear trend which is adjusted to the new price. 


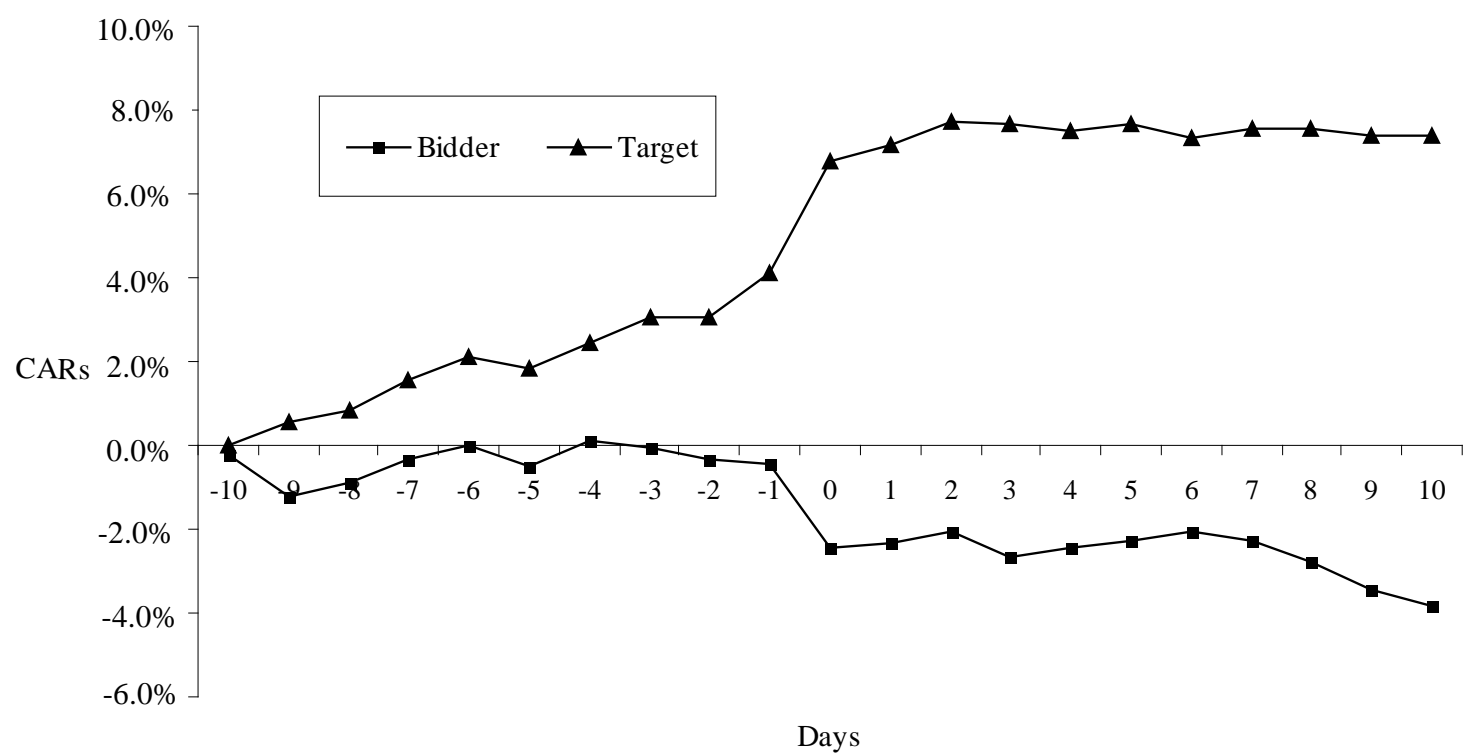

Figure 2. OPA with a change of control (1994-2006). Number transactions: 82. Sample size: 15 bidder and 71 target.

The bidder companies suffer a loss, although they are not always statistically significant. The CARs of the bidder companies take on negative and statistically significant ( $p$-value 0.0000 ) values during the 20 days around the announcement date (CARs $-3.85 \%)$ and in the sub-periods $(0,+1 ; 0,+10)$. The CARs of the target companies, however, are always positive and statistically significant. Within 20 days of the announcement date, they register a value of $+7.39 \%$. However, this value is less than what registered in the OPA without a change of control, and this is partly surprising, because an increase was expected compared with the previous transactions. The change of control should, however, provide for a majority of premium paid by the buyer to acquire the private benefits of control (Zingales, 1994).

The analysis of the sub-periods in Table 5 would seem to confirm the thesis that the bidders' losses are recorded from the day of the event onwards. The sub-period $(0,+10)$, in fact, contains almost all of the loss of the complete period of analysis, with a CARs equal to $-3.41 \%$ ( $p$-value $=0.0000)$. In two sub-periods out of 8 examined $(0 ;+1$ and $0 ;+10)$, the $Z$-test showed a statistical significance of $99 \%$ ( $p$-value $=0.0000)$. More generally, however, in most periods, the values are statistically significant at a confidence level of $90 \%$ and $95 \%$, and this is also confirmed by the low values of the $p$-value. No period prior to the event is statistically significant at $99 \%$. In the 10 days preceding the announcement $(-10,0)$ the cumulative abnormal returns are negative and statistically significant at $95 \%$ (CARs $-2.42 \%$, $p$-value $=0.0463$ ).

\section{The Analysis of Residual Tender Offers}

The residual Tender Offer is launched when the bidder is a shareholder of at least $95 \%$ of the capital represented by securities in an Italian listed company. In this case, he has the obligation to purchase the remaining securities from anyone who requests it. However, if the buyer has a market share of more than 90\% but less than 95\%, he has the obligation to buy the remaining securities admitted to trade on a regulated market from anyone who shall request it, if within 90 days he does not reinstate enough floating funds to ensure regular trading. 
Table 5

Standardized Cumulative Abnormal Returns (CARs) in the OPA With a Change of Control (1994-2006)

\begin{tabular}{|c|c|c|c|c|c|c|c|c|}
\hline \multicolumn{9}{|c|}{ Standardized Cumulative Abnormal Returns (CARs) } \\
\hline \multicolumn{9}{|c|}{ Panel A. Bidders } \\
\hline Period & CAR (\%) & $\begin{array}{l}\text { Standard } \\
\text { Deviation } \\
(\%)\end{array}$ & $Z$-test & $p$-value & Pos. & Neg. & Sign test & Significance \\
\hline$(-10 ;+10)$ & -3.85 & 9.89 & -6.6811 & 0.0000 & 6 & 9 & -0.7746 & ${ }^{* * * *}$ \\
\hline$(-5 ;+5)$ & -2.31 & 8.91 & -1.9017 & 0.0286 & 5 & 10 & -1.2910 & - \\
\hline$(-10 ; 0)$ & -2.42 & 8.94 & -1.6820 & 0.0463 & 8 & 7 & 0.2582 & - \\
\hline$(-5 ; 0)$ & -2.45 & 7.67 & -1.5170 & 0.0646 & 8 & 7 & 0.2582 & - \\
\hline$(-1 ; 0)$ & -2.07 & 7.81 & -0.5889 & 0.2780 & 7 & 8 & -0.2582 & - \\
\hline$(0 ;+1)$ & -1.88 & 8.16 & -8.6236 & 0.0000 & 7 & 8 & -0.2582 & $* * *$ \\
\hline$(0 ;+5)$ & -1.84 & 7.08 & -1.2210 & 0.1110 & 7 & 8 & -0.2582 & - \\
\hline$(0 ;+10)$ & -3.41 & 7.21 & -7.9979 & 0.0000 & 5 & 10 & -1.2910 & $* * *$ \\
\hline \multicolumn{9}{|c|}{ Panel B. Targets } \\
\hline Period & CAR (\%) & S.D. (\%) & $Z$-test & $p$-value & Pos. & Neg. & Sign test & Significance \\
\hline$(-10 ;+10)$ & 7.39 & 15.64 & 12.3151 & 0.0000 & 47 & 24 & 2.7296 & $* * *$ \\
\hline$(-5 ;+5)$ & 5.55 & 14.78 & 6.8121 & 0.0000 & 41 & 30 & 1.3055 & $*$ \\
\hline$(-10 ; 0)$ & 6.77 & 12.53 & 12.4261 & 0.0000 & 51 & 20 & 3.6790 & $* * *$ \\
\hline$(-5 ; 0)$ & 4.65 & 12.61 & 7.0689 & 0.0000 & 47 & 24 & 2.7296 & $* * *$ \\
\hline$(-1 ; 0)$ & 3.09 & 10.76 & 18.6614 & 0.0000 & 45 & 26 & 2.2549 & $* *$ \\
\hline$(0 ;+1)$ & 3.09 & 10.79 & 9.0470 & 0,0000 & 39 & 32 & 0.8307 & - \\
\hline$(0 ;+5)$ & 3.56 & 11.21 & 2.7488 & 0.0030 & 38 & 33 & 0.5934 & - \\
\hline$(0 ;+10)$ & 3.28 & 11.93 & 2.3096 & 0.0105 & 37 & 34 & 0.3560 & - \\
\hline
\end{tabular}

Notes. S.D. = Standard Deviation. $\left({ }^{*}\right),\left({ }^{* *}\right),\left({ }^{* * *}\right)$ Sign test significance at the $10 \%, 5 \%$, and $1 \%$ level.

As shown in Figure 3, the performance of the cumulative residual graph confirms the differences that news of certain transactions has on acquiring and acquired companies. The effects found in the residual OPA are however weaker than the voluntary and mandatory OPA.

These transactions do not seem to have a great effect on the performance of the bidder companies which show, during the 20 days around the announcement date, negative but not statistically significant cumulative abnormal returns (CARs $-0.37 \%$, $p$-value $=0.1526$ ).

The CARs of the target companies during the same period $(-10,+10)$ is $+5.84 \%$, are about half compared to the values recorded in the case of total OPA (CARs $+11.32 \%$ ). The result is still statistically significant for the Z-test ( $p$-value $=0.0000)$.

With regard to the results of the target companies, there are few days when abnormal results are statistically significant. The trend illustrated in the Figure 3 is rather flat until the day of the event where there is the highest increase of the average abnormal residual in one day (ARs $+4.21 \%$ ).

The analysis of the sub-periods in Table 6 shows how most of the average variation recorded by the target companies takes place in the periods $(-1 ; 0)$ and $(0 ; 1)$ with CARs of $+4.53 \%$ and $+4.94 \%$, respectively. Periods in which the $Z$-test assumes particularly high values ( $z$-test $>20$, $p$-value $=0.0000)$.

However, the $Z$-test shows that the results are always statistically significant at $99 \%$, this significance is also confirmed by the Sign test. 


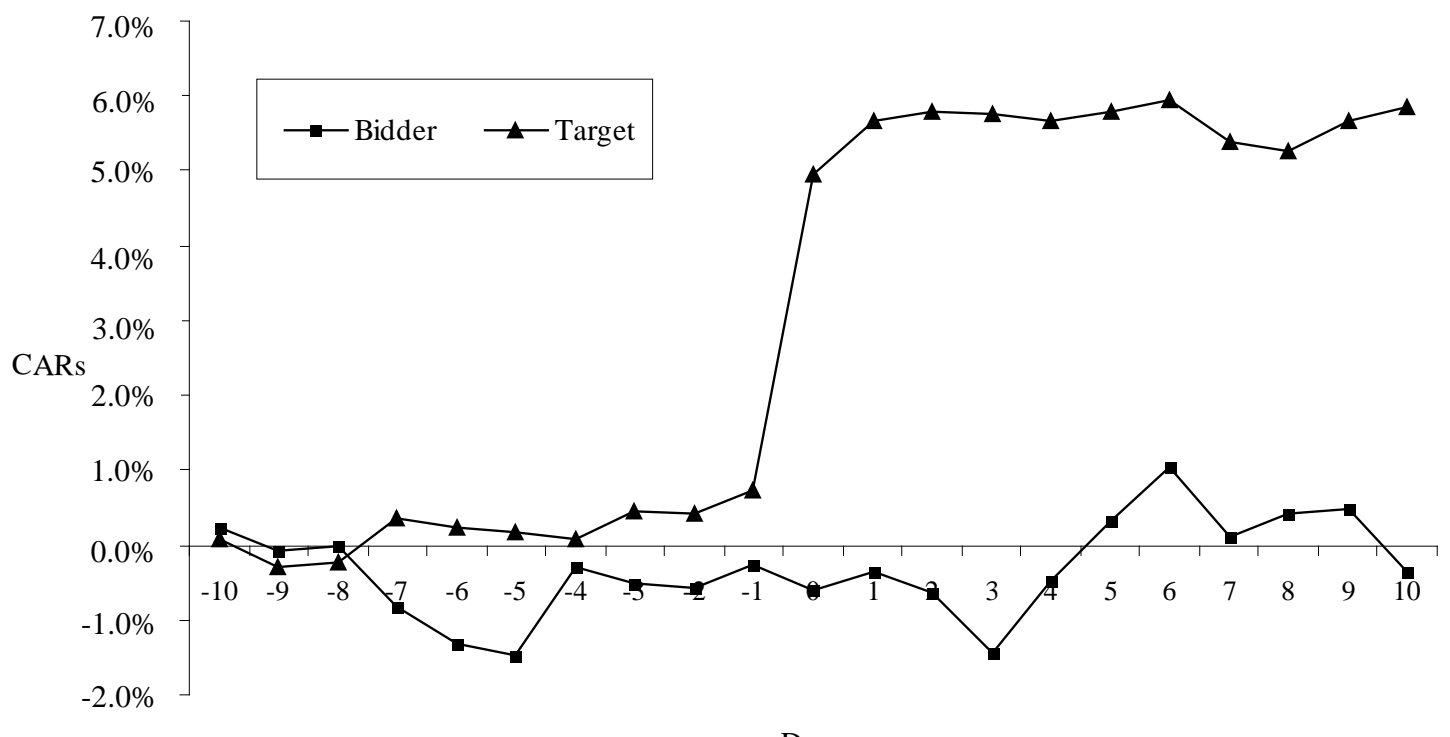

Days

Figure 3. Residual Public Tender Offer (1994-2006). Number transactions: 51. Sample size: 11 bidder and 46 target.

Table 6

Standardized Cumulative Abnormal Returns (CARs) in Residual Public Tender Offers (1994-2006)

\begin{tabular}{|c|c|c|c|c|c|c|c|c|}
\hline \multicolumn{9}{|c|}{ Standardized Cumulative Abnormal Returns (CARs) } \\
\hline \multicolumn{9}{|c|}{ Panel A. Bidders } \\
\hline Period & CARs (\%) & S.D. (\%) & Z-test & $p$-value & Pos. & Neg. & Sign test & Significance \\
\hline$(-10 ;+10)$ & -0.37 & 6.38 & -1.0253 & 0.1526 & 5 & 6 & -0.3015 & - \\
\hline$(-5 ;+5)$ & 1.64 & 6.22 & 2.1694 & 0.0150 & 6 & 5 & 0.3015 & - \\
\hline$(-10 ; 0)$ & -0.61 & 4.88 & -0.7349 & 0.2312 & 3 & 8 & -1.5076 & * \\
\hline$(-5 ; 0)$ & 0.70 & 3.77 & 1.6739 & 0.0471 & 6 & 5 & 0.3015 & - \\
\hline$(-1 ; 0)$ & -0.09 & 1.71 & -0.5032 & 0.3074 & 6 & 5 & 0.3015 & - \\
\hline$(0 ; 1)$ & -0.09 & 1.78 & -3.3744 & 0.0004 & 5 & 6 & -0.3015 & - \\
\hline$(0 ; 5)$ & 0.59 & 5.09 & -2.0902 & 0.0183 & 5 & 6 & -0.3015 & - \\
\hline$(0 ;+10)$ & -0.11 & 7.75 & -1.0157 & 0.1549 & 5 & 6 & -0.3015 & - \\
\hline \multicolumn{9}{|c|}{ Panel B. Targets } \\
\hline Period & CARs (\%) & S.D. (\%) & $Z$-test & $p$-value & Pos. & Neg. & Sign test & Significance \\
\hline$(-10 ;+10)$ & 5.84 & 11.98 & 8.8968 & 0,0000 & 27 & 19 & 1.1795 & - \\
\hline$(-5 ;+5)$ & 5.57 & 9.99 & 7.8685 & 0,0000 & 28 & 18 & 1.4744 & ${ }^{*}$ \\
\hline$(-10 ; 0)$ & 4.94 & 9.76 & 6.8924 & 0,0000 & 30 & 16 & 2.0642 & ** \\
\hline$(-5 ; 0)$ & 4.72 & 8.57 & 7.0980 & 0,0000 & 30 & 16 & 2.0642 & $* *$ \\
\hline$(-1 ; 0)$ & 4.53 & 7.26 & 20.5293 & 0,0000 & 30 & 16 & 2.0642 & ** \\
\hline$(0 ; 1)$ & 4.94 & 8.29 & 20.4150 & 0,0000 & 32 & 14 & 2.6540 & **** \\
\hline$(0 ; 5)$ & 5.06 & 9.23 & 3.4998 & 0,0002 & 29 & 17 & 1.7693 & ${ }^{* *}$ \\
\hline$(0 ;+10)$ & 5.12 & 10.37 & 4.7983 & 0,0000 & 26 & 20 & 0.8847 & - \\
\hline
\end{tabular}

Notes. S.D. = Standard Deviation. $\left({ }^{*}\right),\left(^{* *}\right),\left(^{* * *}\right)$ Sign test significance at the $10 \%, 5 \%$, and $1 \%$ level.

In the final analysis, the bidder companies seem to be indifferent to these transactions, having probably paid for the effects of the acquisition in the previous voluntary or mandatory OPA. 


\section{The Analysis of the Combined Values}

The analysis of the combined values is aimed at assessing the creation of overall value which occurs following the acquisition transactions. In this work, 23 transactions were examined and the values of the Combined Cumulative Abnormal Returns Standardized (CCARs) reveal that Tender Offers do not create value for shareholders (see Table 7).

Table 7

Combined Cumulative Abnormal Returns (CCARs) in OPA (1994-2006)

\begin{tabular}{|c|c|c|c|c|c|c|c|}
\hline Period & CCARs (\%) & S.D. (\%) & $Z$-test & $p$-value & Pos. & Neg. & Sign test \\
\hline$(-10,0)$ & -1.13 & 7.03 & -0.4589 & 0.3232 & 14 & 9 & $2.3452^{* * * *}$ \\
\hline$(-10,+10)$ & -0.56 & 7.46 & -2.4273 & 0.0076 & 12 & 11 & $7.0356^{* * *}$ \\
\hline
\end{tabular}

Notes. S.D. $=$ Standard Deviation. $\left.\left({ }^{*}\right),\left({ }^{* *}\right),{ }^{* * *}\right)$ Sign test significance at the $10 \%, 5 \%$, and $1 \%$ level.

In the periods examined $(-10,0)$ and $(-10,+10)$, the sample showed a destruction of value of $-1.13 \%$ and $-0.56 \%$, respectively. The data, however, are statistically significant for both the Z-test and the Sign test.

\section{Conclusions}

The results obtained in this work are in line with international literature on Tender Offers. In general, the shareholders of the target companies register positive and statistically significant values throughout the whole period (CARs $+11.32 \%$ ), while the shareholders of the bidder companies do not gain from the Tender Offer transactions (CARs -1.05\%). Even if the values do not always appear statistically significant for the bidders, they are however always negative, just like other works on Mergers and Tender Offers that verify returns in time windows similar to those examined in this work (Dodd, 1980; Asquith, Bruner, \& Mullins, 1990; Veraiya \& Ferris, 1987; Kaplan \& Wiesbach, 1992; Franks, Harris, \& Titman, 1991; Eckbo \& Thorburn, 2000; Gosh, 2004; Kuipers, Miller, \& Patel, 2008).

The analysis of the combined values creates negative and statistically significant values which are close to zero. From this point of view, the results on the one hand confirm and strengthen those obtained in a previous study (Intrisano \& Rossi, 2012); on the other hand, they differ with respect to the conclusions reached by international literature on Tender Offers, which generally shows positive values, although not always statistically significant (Smith \& Kim, 1994; Bradley, Desai, \& Kim, 1988; Lang, Stulz, \& Walkling, 1989; Berkovitch \& Nerayanan, 1993).

In conclusion, even though the destruction of value in the period around the announcement date is modest (CARs $-0.56 \%$ ), these transactions, rather than creating value, produce the transfer of value by the shareholders of the bidder companies to those of the target companies, which ultimately results in a "zero sum".

\section{References}

Agrawal, A., \& Jaffe, J. (1996). The pre-acquisition performance of target firms: A re-examination of the inefficient management hypothesis. Rodney L. White Center for Financial Research working paper No. 6-96. Retrieved from http://www.ssrn.com/abstract=7643

Asquith, P., Bruner, R., \& Mullins, D. (1990). Mergers returns and the form of financing. Working paper \#3203-90-EFA. Retrieved from http://www.dspace.mit.edu/bitstream/handle/1721.1/2319/SWP-3203-22601312.pdf

Autorità Garante Concorrenza e Mercato. (Various years). Annual report. Rome.

Banerjee, A., \& Owners, J. (1992) Wealth reduction in knight bids. Financial Management, 21, 48-57.

Berkovitch, E., \& Nerayanan, M. P. (1993). Motives for takeovers: An empirical investigation. Journal of Financial and Quantitative Analysis, 28(3), 347-362. 
Bigelli, M., \& Mengoli, S. (1999). Acquisizione di imprese e benefici privati dei gruppi di controllo: alcune evidenze empiriche per il mercato italiano. Finanza, Marketing e Produzione, 1, 87-114.

Bradley, M. (1980). Interfirm tender offers and the market for corporate control. Journal of Business, 53(4), 345-376.

Bradley, M., Desai, A., \& Kim, E. H. (1988). Synergistic gains from corporate acquisitions and their division between the stockholders of target and acquiring firms. Journal of Financial Economics, 21(1), 3-40.

Brown, S., \& Warner, J. (1980). Measuring security price performance. Journal of Financial Economics, 8(1), 205-258.

Brown, S., \& Warner, J. (1985). Using daily stock returns: The case of event studies. Journal of Financial Economics, 14(1), 3-31.

Bruner, R. F. (2003). Does M\&A pay? Retrieved from http://www.papers.ssrn.com/sol3/papers.cfm?abstract_id=306750

Byrd, J., \& Hickman, K. (1992). Do outside directors monitor managers? Evidence from tender offers bids. Journal of Financial Economics, 32(2), 195-221.

Caprio, L., Floreani, A., \& Radaelli, L. (1994). I trasferimenti del controllo di società quotate in Italia: un'analisi empirica dei prezzi e dei risultati per gli azionisti di minoranza. Finanza Imprese e Mercati, 3, 355-392.

Commissione Nazionale per le Società e la Borsa (CONSOB). (various years). Annual report. Rome.

Dodd, P. (1980). Merger proposals, management discretion and stockholder wealth. Journal of Financial Economics, 8(2), 105-138.

Dodd, P., \& Ruback, R. (1977). Tender offers and stockholder return: An empirical analysis. Journal of Financial Economics, 5(3), 351-374.

Eckbo, E., \& Thorburn, K. (2000). Gains to bidder firms revisited: domestic and foreign acquisitions in Canada. Journal of Financial and Quantitative Analysis, 35(1), 1-25.

Fama, E. F., Fisher, L., Jensen, M. C., \& Roll, R. (1969). The adjustment of stock prices to new information. International Economic Review, 10(2), 1-21.

Franks, J., Harris, R., \& Titman S. (1991). The postmergers share-price performance of acquiring firms. Journal of Financial Economics, 29(1), 81-96.

Gosh., A. (2004). Increasing market shares as a rationale for corporate acquisitions. Journal of Business Finance \& Accounting, 31(1-2), 209-247.

Intrisano, C., \& Rossi, F. (2012). Do M\&A generate value for shareholders? An analysis of the Italian banking sector. Chinese Business Review, 11(2), 206-216.

Jarrell, G., \& Bradley, M. (1980). The economic effects of federal and state regulations of cash tender offers. Journal of Law and Economics, 23, 371-407.

Jarrell, G., \& Poulsen, A. (1989). The returns to acquiring firms in tender offers: Evidence from three decades. Financial Management, 18, 12-19.

Jarrell, G., Brickley, J., \& Netter, J. (1988). The market for corporate control: The empirical evidence since 1980. Journal of Economic Perspectives, 2(1), 49-68.

Jensen, M. C., \& Ruback, R. (1983). The market for corporate control: The scientific evidence. Journal of Financial Economics, 11(1), 5-50.

Jennings, R. H., \& Mazzeo, M. A. (1991). Stock price movements around acquisition announcements and management’s response. Journal of Business, 64(2), 139-163.

Kaplan, S., \& Weisbach, M. (1992). The success of acquisitions: Evidence from divestitures. Journal of Finance, 47(1), 107-138.

Kummer, D., \& Hoffmeister, R. (1978). Valuation consequences of cash tender offers. Journal of Finance, 33(2), 505-516.

Kuipers, D., Miller, D., \& Patel, A. (2008). The legal environment and corporate valuation: Evidence from cross-border takeovers. Retrieved from http://www.papers.ssrn.com/sol3/papers.cfm?abstract_id=277488

Lang, L., Stulz, R., \& Walkling, R. (1989). Managerial performance, Tobin’s Q, and the gains from successful tender offers. Journal of Financial Economics, 24(1), 137-154.

Mediobanca. (2007). Indices and data on investments in listed securities. Milano: Annual Book.

Mulherin, H., \& Boone, A. (2000). Comparing acquisitions and divestitures. Journal of Corporate Finance, 6, 117-139.

Mulherin, H., \& Boone, A. (2006). How are firms sold? Retrieved from http://www.papers.ssrn.com/sol3/papers.cfm?abstract_id=642306

Patell, J. M. (1976). Corporate forecast of earnings per share and stock price behavior: Empirical tests. Journal of Accounting Research, 14, 246-276. 
Resti, A., \& Siciliano, G. (1999). Le acquisizioni di banche quotate creano valore per gli azionisti? Un confronto tra i prezzi di borsa ed i dati fondamentali di alcune banche italiane. Banca Impresa Società, 1, 93-124.

Rossi, F. (2005). Strutture proprietarie e benefici privati di controllo. Roma: Aracne Editore.

Savona, R. (2002). Fusioni e acquisizioni bancarie in Italia, 1989-1997: un’analisi empirica sulla reattività dei prezzi azionari. Bancaria, 1, 31-52.

Servaes, H. (1991). Tobin's Q and the gains from takeovers. Journal of Finance, 46(1), 409-419.

Smith, R., \& Kim, J. (1994). The combined effects of free cash flow on bidder and target stock returns. Journal of Business, 67(2), 281-310.

Sirower, M. (1997). The synergy trap: How companies lose the acquisition game. New York: The Free Press.

Varaiya, N., \& Ferris, K. (1987). Overpaying in corporate takeover: The winner’s curse. Financial Analyst Journal, 43(3), 64-70.

Zingales, L. (1994). The value of voting right: A study of the Milan Stock Exchange experience. The Review of Financial Studies, 7(1), 125-148. 